\title{
Empirical Research on the Influential Factors of Students' Preference on College Elective English Courses Based on the Principal Component Analysis
}

\author{
HE Quan ${ }^{1, a}$, WU Tian ${ }^{2, b}$, Yin Pi'an ${ }^{3, c}$ \\ ${ }^{1,3}$ School of Humanities and Foreign Languages, Xi'an University of Technology \\ ${ }^{2}$ School of Finance, Xi'an Eurasia University \\ a,b,c hequan2012@yeah.net
}

Keywords: college English; elective course; student preference; principal component; analysis; diversification

\begin{abstract}
With the increasing diversity of university courses and the improvement and promotion of freedom elective system, college English courses are also gradually incorporated into the range of elective courses. And it is found that students have obvious preferences in the choice of those courses; these preference are particularly evident in college English Elective courses. This paper firstly analyzes the current situation of college English elective courses, using the principal component analysis method carries out research on a variety of influencing factors of university English elective student preference, on this basis, to further empirical research on their preferences impact factors, eventually it can be found that the preference influence factors of students play a role in promoting for the diversification adjustment of college English elective courses.
\end{abstract}

\section{Introduction}

In recent years, the successive years of enrollment of the major universities makes the college education objects appear unprecedented polarization state, and after college English is classified as elective courses, this polarization is significantly expanding trend. In order to change the college English learning and college English educational situation, thus perfecting university elective courses system, many experts, some scholars and the educators carry out the analysis and researches in view of Influential factors of students' preferences in College elective English courses [1]. Ye Tanglin carries on a research review from the students' learning motivation, participation motivation, elective motivation at home and abroad, influential factors and other related aspects of university electives, he confirms the influential factors of college English elective courses that derive from the human motivation, cognitive, the affective and social factors, at the same time the self learning ability and working demand are also the influential factors; in the requirement analysis theoretical framework, Tan Xinyu conducts an integrative analysis of extrinsic and intrinsic factors affecting students' choices of the elective courses, he finds that only reasonable setting in college English elective courses is able to cultivate the demanded talents to meet the social needs ; Wang Junsheng studies $t$ multiple effecting factors why the students select the English elective courses via the one-by-one analysis mathematical model, determining the weights and value of all influential factors, finally after an experiment to prove, he draws that the credit system has a decisive role in the students' choices of college English elective courses; under the credit system, Shi Xiaoyan, Zhou Ruifang and Li Sufan find that the school institutional factors are more outstanding than others or personal factors influencing the students' intentions of English elective courses [2].

English learning is interacted and mutually affected by English knowledge and its recognition, and the individual learning strategies, and the English learning process is very complex. As the individual activity increases, the number of mental lexicon also will be on the rise quickly steadily [3]. Mental lexicon is mainly stored in the long-time memory, short-term memory and long-time memory can be transformed into each other, and the mental lexicon will change in accordance with the external conditions. English memory diagram is shown in Figure 1. 


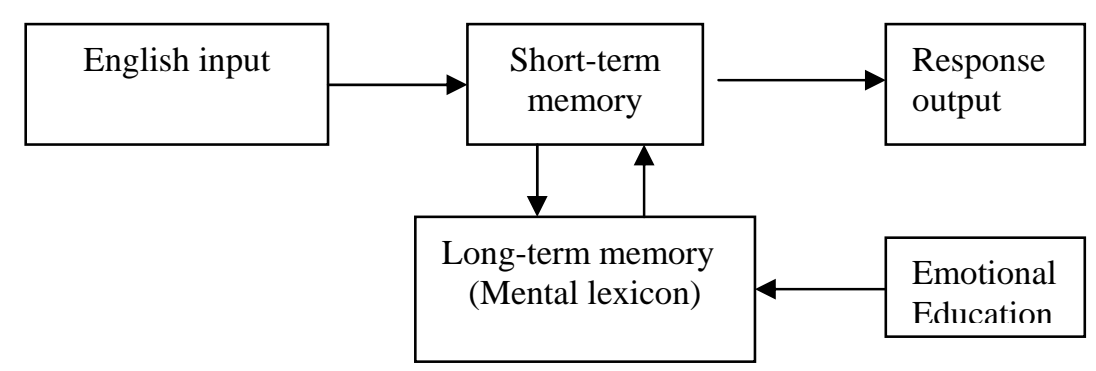

Figure 1. Schematic diagram of English vocabulary memory

From Figure 2, it can be seen that English language is inputted into the human brain, which first generates a short-term memory effects. At the same time, short-term memory can be converted into long-time memory, input words are converted into the mental lexicon, and the emotional education can act on the long-time memory, thus promoting the mental vocabulary formation [4]. When extracting the mental lexicon, long-time memory is converted into short-term memory, then to carry on response output.

On College students' English learning, college students' emotion is of great complexity. In school's four years study and life, the students' emotional state is constantly changing, this is because the students have a strong thirst for knowledge, in this process of different information, the students' emotional states can lead to great fluctuations. However, college students are more sensitive to emotional changes, at different stages; college students' emotional performance is different so that the emotional factors are diverse
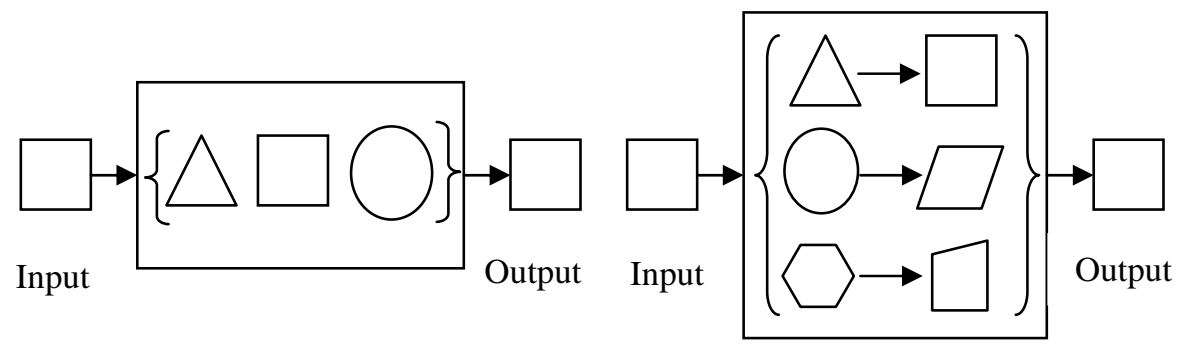

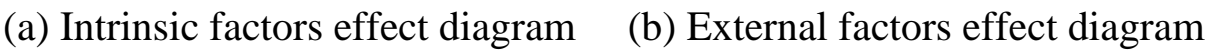

Figure 2. Emotional education effecting diagram

The main factors which influence college student's emotional preference can be divided into internal factors and external factors, in which internal factors refer to the emotionally mental activities, external factors refer to things influencing the individuals outside. University students' emotional education factors are shown in Figure 2.

From the lessons learned, the Chinese government and the major local governments have prepared their own disaster management information systems to handle suddenly occurring natural disasters. But, these systems are, sort of, first generation system, and they can't handle the disasters caused by the earthquake efficiently [2]. So in this paper, we present a building earthquake disaster simulation system, which can estimate the damage of the earthquake and present the destroyed results visually.

\section{Analysis on the present situation of college English elective curriculum}

1)The relationship between social demand and college English elective education

With the evolution reform of college English education teaching, many universities are required to offer a series of college English elective courses, although this reform enriches the college English courses system, it will inevitably encounter some problems in the process of implementation [5]. The establishment of college English courses is to enrich the university curriculum, at the same time to improve the overall qualities of students. Nowadays, with the development of market-driven economy and economic globalization, English has become a necessity to global economic and trade 
development. For the purpose of cultivation of talents, it needs a person with a good command of English communicate skills.

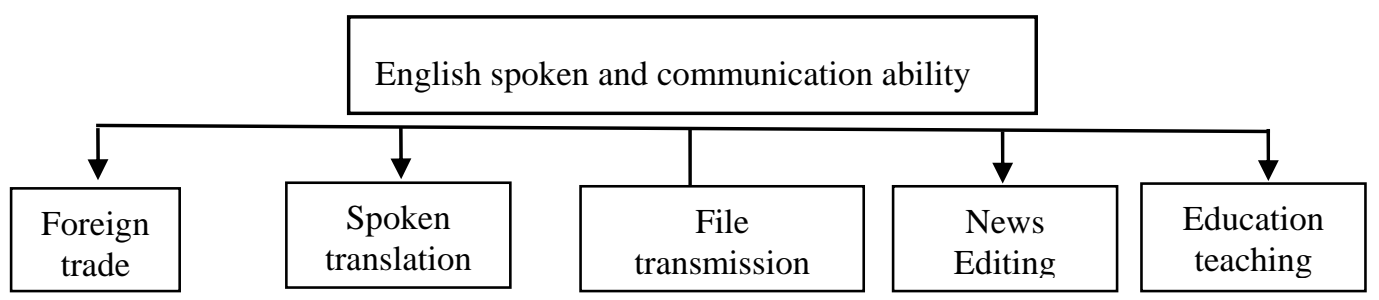

Figure 3. Social application of spoken English and communication ability

The launching of college English elective courses can reflect the autonomy of students as well as teachers dominant, which should take into account language skills development and English language cultural transmission, to avoid the separation problem of listening, speaking, reading, writing and translating in the traditional teaching [6]. However in reality, the school leadership do not pay due attention to elective courses, on the basis of meeting the students' personality development, the school increases teachers' teaching tasks for an honor, to make the college English education into dilemma. The increasing number of college English elective courses is only expanded, but the implementation of elective courses is neglected, which may be the biggest disadvantage of college English elective courses. Even worse, to improve English is to meet the social needs and school requirements, but to ignore the demands of an individual to promote self-improvement and the cultivation of one's abilities.

2) Positive relationship analysis on students and college English elective courses

At present, learning English aims to improve the practical skills such as listening and speaking skills. [7]. English learning is supposed to meet the needs of different professional development, it is feasible for the students of the low starting point to gradually improve the overall English level, and for the top students, to be provided with more learning opportunities. So college English elective courses are able to better meet the students' needs of learning.

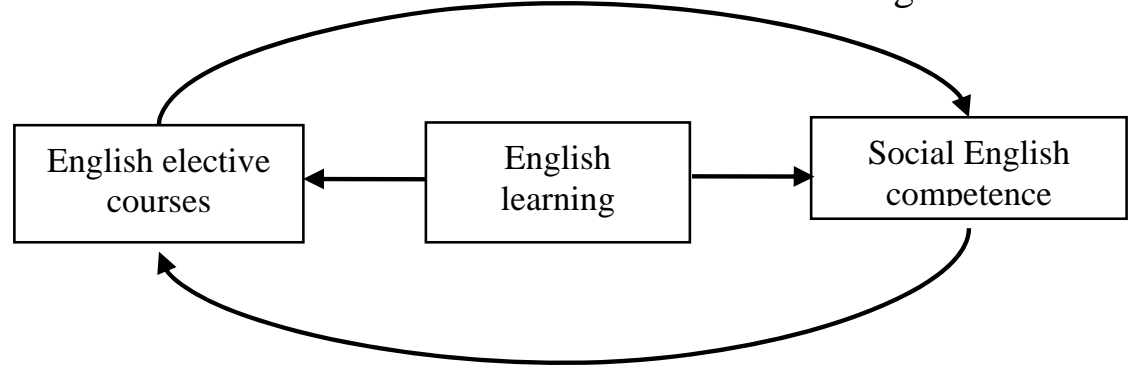

Figure 4. The learning of English ability, education and demand positive relationship diagram

The nature of learning English is that the learners should initiatively learn a language based on their existing knowledge and experience. Learners are the subjects of cognition, but also active construction of knowledge awareness, and when the society has a demand for the talents with English competence, the positive relationship between college English elective education and students' English learning can be clearly demonstrated in the educational mode of most of the colleges. This shows that the nowadays English learning activities among the college students are habitual learning under the social demand and school requirements instead of "creative learning" advocated by the educational circle.

\section{Conclusion}

Through the principal component analysis method conducted on students' preferences of college English elective courses, it is found that the influential factors of students' preference to college English elective courses are from the students themselves, however more impact factors come from the social environment and education system, because the normal relations model of social demands and education direction have been insufficient to pull the enthusiasm of the students' independent 
learning English. In this study, high school students on the preference factor impact of the College English elective courses indicate that students need to develop the innovative learning attitude, that is to say, in the context of social demands and education methods, we should also consider the students' intrinsic interest and independent learning enthusiasm, to construct a reasonable of college English elective courses diversity mode.

\section{Acknowledgements}

Sponsored by A systematical study of the College English extracurricular activities, NO. 109-00j1102

\section{References}

[1] Richard Peterson, "The persistence of low expectations in special education law viewed through the lens of therapeutic jurisprudence", International Journal of Law and Psychiatry, Vol.33, No.5, pp.375-397,2010.

[2] Mary E. Zellmer-Bruhn, Mary M. Maloney, Anita D. Bhappu, Rommel (Bombie) Salvador, "When and how do differences matter? An exploration of perceived similarity in teams" ,Organizational Behavior and Human Decision Processes, Vol.107,No.1, pp.41-59 , 2008.

[3] Xu Huijian, Guo Feipeng, "Combining Rough Set and Principal Component Analysis for Preprocessing on Commercial Data Stream", JCIT: Journal of Convergence Information Technology, Vol. 7, No. 2, pp. 132-140, 2012

[4] Peter Ghosh, "Max Weber, Werner Sombart and the Archiv für Sozialwissenschaft: The authorship of the 'Geleitwort' (1904) ",History of European Ideas, Vol.36,No.1,pp.71-100,2010.

[5] Stacey S. Horn, "Heterosexual adolescents' and young adults' beliefs and attitudes about homosexuality and gay and lesbian peers",Cognitive Development, Vol.21, No.4, pp.420-440, 2006.

[6] Yasser Fouad Hassan, Nora Habeb, "Hybrid System of PCA, Rough Sets and Neural Networks for Dimensionality Reduction and Classification in Human Face Recognition", IJIIP: International Journal of Intelligent Information Processing, Vol. 3, No. 1, pp. 16-24, 2012.

[7] Anton Oleinik, "Does education corrupt? Theories of grade inflation",Educational Research Review, Vol.4,No.2,pp.156-164,2009. 